\title{
Kesan Pemendapan Elektroforesis Gam Arab terhadap Halaju Kakisan pada Aluminium 5052
}

(Electrophoresis Deposition Arabic Gum Effect on Aluminium 5052 Reduce Corrosion)

\author{
I Gusti AyU ARWATI, Edy Herianto MAJLAN*, WAN RAMLi WAN DAUd, LOH KeE SHYUAN, KHUZAIMAH BINTI \\ ARIFIN, TEUKu HuSAINI, SAGIR ALVA \& NABILAH AFIQAH MOHD RADZUAN
}

\author{
ABSTRAK
}

Plat dwikutub adalah salah satu komponen utama sel fuel membran pertukaran proton (PEMFC). Aloi aluminium (Al5052) merupakan salah satu logam yang digunakan sebagai plat dwikutub kerana mempunyai kekonduksian yang tinggi dan ringan. Namun, sistem PEMFC yang berasid (pH3-6) adalah mudah untuk bahan Al5052 mengalami kakisan sehingga dapat mengurangkan prestasi PEMFC. Oleh itu, bagi mengurangkan halaju kakisan yang berlaku, kajian ini menggunakan perencat hijau gam Arab dengan kaedah pemendapan elektroforesis (EPD). Kesan kakisan plat Al5052 bersalut 0.5 $\mathrm{gL}^{-1}$ gam Arab di dalam larutan sulfurik asid diuji menggunakan kaedah elektrokimia dan ujian morfologi. Hasil ujian morfologi permukaan Al5052 yang bersalut gam Arab terlihat lebih halus dan homogen berbanding permukaan yang tidak disalut serta hasil keratan rentas ketebalan salutan adalah antara $7.5 \mu$ m sehingga $8.8 \mu$ m. Kesan peningkatan suhu $\left(30^{\circ} \mathrm{C}\right.$ sehingga $\left.90^{\circ} \mathrm{C}\right)$ terhadap nilai rintangan hubungan antara muka (ICR) pada Al5052 yang tidak bersalut akan menurun daripada 11.8552 sehinggs $9.9042 \mathrm{~m} \Omega \mathrm{cm}^{2}$ manakala yang bersalutkan gam Arab mempunyai nilai daripada 13.3497sehingga $11.812 \mathrm{~m} \Omega \mathrm{cm}^{2}$. Keputusan menunjukkan bahawa gam Arab dapat memberikan perlindungan terhadap permukaan logam yang apabila pengujian menggunakan kaedah polarisasi linear tafel dalam larutan $0.5 \mathrm{M} \mathrm{H}_{2} \mathrm{SO}_{4}$ (pH4) menunjukkan nilai ketumpatan arus kakisan ( $I_{\text {corr }}$ ) semakin menurun daripada 0.00264 kepada $0.00012 \mu \mathrm{A} \mathrm{cm}^{-2}$. Selain itu, halaju kakisan turut menurun daripada $3.06 \times 10^{-5}$ mpy kepada $1.61 \times 10^{-6}$ mpy setelah disalut gam Arab. Kesimpulannya, gam Arab dan kaedah salutan EPD boleh digunakan bagi mengurangkan halaju kakisan pada plat Al5052, supaya jangka hayat bahan ini lebih panjang dan boleh mencapai piawai yang ditetapkan oleh DOE untuk plat dwikutub.

Kata kunci: Aluminium 5052; ketumpatan arus kakisan; pemendapan elektroforesis; perencat hijau gam arab; plat dwikutub; rintangan hubungan antara muka

\section{ABSTRACT}

Bipolar plates are one of the main components of proton exchange membrane fuel cells (PEMFC). Aluminum alloy (Al5052) is one of the metals used as a bipolar plate because it has a high conductivity, light weight. However, the acidic PEMFC system (pH3-6) is easy for Al5052 ingredients to experience corrosion so as to reduce PEMFC achievement. Therefore, in order to reduce the prevailing sidewalks, this study used a green Arabic gum inhibitor with an electrophoresis deposition (EPD). The impression of a $0.5 \mathrm{gL}^{-1}$ Arabic gum-coated Al5052 plate sidewalk in the sulphuric acid solution was tested using an electrochemical method and a morphological test. The surface morphology of Al5052 coated with Arabic gum appeared to be smoother and homogeneous compared to uncoated surface and the cross section of the coating thickness was between $7.5 \mu \mathrm{m}$ and $8.8 \mu \mathrm{m}$. Effect of temperature increase $\left(30^{\circ} \mathrm{C}-90^{\circ} \mathrm{C}\right)$ on the interfacial contact resistance (ICR) value of the uncoated Al5052 will decrease from 11.8552 to $9.9042 \mathrm{~m} \Omega \mathrm{cm}^{2}$ where the Arabic gum coated has a value of 13,3497 to $11,812 \mathrm{~m} \Omega \mathrm{cm}^{2}$. The results showed that Arabic gum can provide protection against metal surfaces where the test using linear tafel polarization technique in $0.5 \mathrm{M} \mathrm{H}_{2} \mathrm{SO}_{4}(\mathrm{pH})$ solution with corrosion current value (I $\left.\mathrm{I}_{\text {cor }}\right)$ decreased

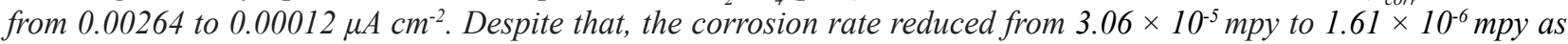
being coted with Arabic gum. It can be concluded that Arabic gum and coating techniques with EPD can be used to reduce corrosion on the Al5052 plate, therefore, the life span of this material is longer and may reach the targets set by the DOE for bipolar plates.

Keywords: Aluminium 5052; bipolar plates; corrosion current density; electrophoresis deposition; green inhibitor arabic gum; interfacial contact resistance

\section{PENGENALAN}

Sel fuel membran pertukaran proton (PEMFC) merupakan salah satu daripada alat tenaga alternatif yang sedang dibangunkan dalam usaha bagi mengurangkan kebergantungan kepada bahan bakar fosil (Antunes et al. 2011; Herman et al. 2005). Pembangunan teknologi PEMFC yang pesat ini membolehkannya digunakan dalam pelbagai aplikasi, memandangkan keupayaannya yang 
bebas daripada pencemaran karbon dioksida $\left(\mathrm{CO}_{2}\right)$, serta suhu operasi sekitar $60^{\circ} \mathrm{C}$ hingga $100^{\circ} \mathrm{C}$ (Antunes et al. 2010; Mehta et al. 2003). PEMFC terdiri daripada beberapa komponen dengan salah satu komponen terpenting adalah plat dwikutub.

Plat dwikutub kebanyakannya diperbuat daripada bahan berunsur grafit, bahan komposit dan bahan berunsur logam (De Olivera et al. 2012; Shahran Karim et al. 2012). Walaupun bahan berunsur grafit dan bahan komposit tahan terhadap kakisan namun, ia mempunyai sifat kekonduksian elektrik yang lebih rendah jika dibandingkan dengan bahan logam. Nilai ketahanan kakisan pada plat dwikutub berdasarkan sasaran Jabatan Tenaga Amerika (US-DOE), haruslah mempunyai ketumpatan arus $\left(\mathrm{I}_{\text {Corr }}\right)$ kurang daripada $1 \mu \mathrm{A} \mathrm{cm} ~^{-2}$ dan nilai rintangan hubungan antara muka (ICR) kurang daripada $20 \mathrm{~m} \Omega \mathrm{cm}^{2}$ (Asri et al. 2017). Sifat ini hanya dapat dimiliki oleh logam seperti, logam tahan karat, aluminium dan titanium. Oleh itu, bahan logam ini sering diguna pakai sebagai bahan bagi plat dwikutub PEMFC (Antunes et al. 2011; Asri et al. 2016; Herman et al. 2005).

Logam A15052 merupakan logam terbaik untuk plat dwikutub memandangkan ia ringan, murah, mudah diperoleh serta mudah diubah suai mengikut kesesuaian penggunaan (Hou 2011; Mohd Radzuan et al. 2017). Namun begitu, memandangkan sifat halaju kakisan bahan yang tinggi, beberapa pendekatan telah diambil antaranya adalah dengan menggunakan kaedah penyalutan (Dadfar et al. 2016; Umoren et al. 2008b; Tawfik et al. 2007). Kriteria pemilihan bahan dan teknik salutan adalah sangat penting kerana akan mempengaruhi sifat pasif yang terbentuk pada permukaan logam (Yang et al. 2010). Contoh bahan salutan yang bersifat konduktif antaranya adalah salutan logam menggunakan logam nitrida dan logam karbida (Mehta \& Cooper 2003; Tawfik et al. 2007; Woodman et al. 1999). Antara salah satu kaedah salutan yang popular digunakan adalah kaedah pemendapan wap fizikal (PVD). Namun, hasil ujian ke atas salutan pada permukaan logam dengan analisis morfologi menggunakan alatan mikroskopi elektron imbasan (SEM) menunjukkan terdapat beberapa lubang kakisan terbentuk (Huang et al. 2016). Keadaan ini membuktikan bahawa kegagalan salutan ini berpunca daripada keadaan salutan yang tidak rata pada permukaan logam.

Kawalan terhadap kakisan bahan logam amatlah penting sebagai salah satu bahan yang boleh diguna pakai untuk mengurangkan kakisan adalah dengan menggunakan perencat. Salutan pada permukaan logam menghalang pembebasan ion logam serta mengekang kakisan berlaku dalam tempoh masa yang singkat (Ameh 2014; Ameh et al. 2012). Perencat kromat sering digunakan sebagai perencat kakisan pada logam. Namun, sifatnya mengekang penggunaan yang bertoksik serta membahayakan pengguna dan alam sekitar. Oleh itu, jenis perencat hijau terbiodegradasi merupakan alternatif masa kini yang merupakan kunci kepada pembangunan teknologi (Patni et al. 2013; Peter \& Sanjay 2015; Sangeetha et al. 2011). Penggunaan perencat hijau sebagai bahan alternatif yang dapat mengurangkan kakisan pada logam mengandungi beberapa sebatian organik. Antaranya adalah Oksigen $(\mathrm{O})$, Nitrogen (N), Fosforus (P) dan Sulfur (S) yang berupaya membentuk lapisan filem pasif (Rani \& Basu 2012). Berdasarkan penerangan tersebut, kajian ini menjurus kepada penggunaan bahan gam Arab perencat hijau yang mampu meningkatkan kesan penyerapan pada permukaan logam (Othman et al. 2012). Gam Arab perencat hijau sering digunakan sebagai satu bahan salutan dan kini ia diterapkan dalam pembangunan bahan plat dwikutub bagi aplikasi sel fuel memandangkan keupayaannya untuk mengekang kakisan di samping mengalirkan arus elektrik (Babu et al. 2018). Terdapat beberapa jenis kaedah yang biasa digunakan untuk salutan pada permukaan logam antaranya adalah melalui kaedah pemendapan EPD. Kajian menggunakan EPD ini adalah lebih selamat dan mudah untuk digunakan jika dibandingkan dengan kaedah salutan lain seperti pemendapan wap fizikal, pemendapan wap kimia dan penyemburan (Feng et al. 2013; García \& Smit 2006; Pech-Rodríguez et al. 2014). Proses EPD menghasilkan molekul yang melarut dalam larutan akueus atau organik yang dipindahkan ke elektrod apabila dialirkan arus elektrik (Antonelli et al. 2013; Garcia et al. 2006; Pech et al. 2014; Peter \& Sanjay 2015; Raddaha et al. 2014). Bagi mencapai deposit struktur zarah elektroforetik yang seragam mengikut ia bergantung kepada jumlah kepekatan larutan, $\mathrm{pH}$ dan kekonduksian gam Arab. Kaedah EPD ini menawarkan hasil salutan yang sekata, alatan yang mudah diperoleh, serta ketebalan yang mudah dikawal berdasarkan kesesuaian aplikasi (Raddaha et al. 2014). Oleh itu, kajian ini menekankan penggunaan bahan gam Arab menggunakan kaedah EPD pada permukaan logam A15052 yang mampu meningkatkan sifat rintangan dan kakisan serta meningkatkan prestasi keseluruhan plat dwikutub.

\section{BAHAN DAN KAEDAH}

\section{PROSES PENYALUTAN SECARA ELEKTROFORESIS}

Logam yang digunakan dalam kajian ini adalah plat A15052 yang terdiri daripada unsur logam dengan komposisi seperti , 0.45 wt. $\% \mathrm{Si}, 0.45$ wt. $\%$ Fe, 0.1 wt. $\% \mathrm{Cu}, 0.1$ wt. $\% \mathrm{Mn}, 2.2$ wt. $\% \mathrm{Mg}, 0.15$ wt. $\%$ Cr, 0.1 wt. $\% \mathrm{Zn}$ dan 96.45\% (Al) (Chiang et al. 2014). Bahan salutan yang digunakan adalah gam Arab perencat hijau berasal daripada pokok akasia (G9752-500G) yang diperoleh daripada Sigma Chemical (St Louis, MO). Bahan gam Arab ini terdiri daripada struktur rantaian polisakarida seperti yang ditunjukkan dalam Rajah 1 dan pencirian bahan gam Arab dalam Jadual 1. Struktur rantaian polisakarida ini terdiri daripada unsur D-galaktopiranosa (GALP) yang dihubungkan dengan L-Arabofuranose (ARAF), L-Rhamnopyranose (RHAP) dan asid D-Glucuronic (GA).

Bahan logam Al5052 berukuran $2.5 \mathrm{~cm} \times 2.5 \mathrm{~cm} \times 3$ $\mathrm{mm}$, sebelum penyalutan permukaan logam dibersihkan dengan menggunakan mesin pengilap mekanikal (model Mecapol press) bersama kertas pasir bergred 800 dan 

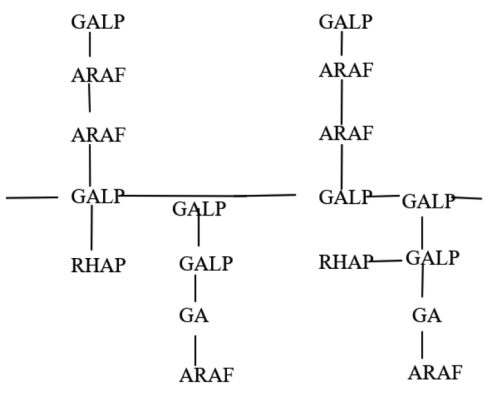

RAJAH 1. Struktur rantaian polisakarida bagi gam Arab

JADUAL 1. Pencirian bahan asal gam Arab

\begin{tabular}{lc}
\hline Kebolehlarutan & $1 \mathrm{~g} / 2 \mathrm{~mL}$ air \\
\hline Jumlah abu & $<4 \%$ \\
Ketidaktelapan asid & $<0.5 \%$ \\
\hline
\end{tabular}

1500. Seterusnya, permukaan logam dibersihkan dengan menggunakan cecair aseton agar permukaan logam bebas daripada kotoran. Penyediaan permukaan logam yang sempurna adalah penting bagi membolehkan penyalutan yang sekata dilakukan. Sebanyak $0.5 \mathrm{~g}$ (0.05 vol.\%) gam Arab yang dilarutkan bersama dengan $1000 \mathrm{~mL}$ air suling. Kemudian larutan gam Arab tersebut ditempatkan di atas pemanas $\left(60^{\circ} \mathrm{C}\right)$ dan dicampurkan menggunakan pengaduk magnet selama 30 minit sehingga adunan menjadi sekata. Larutan kemudiannya dibiarkan menyejuk pada suhu bilik sebelum digunakan untuk menyalut bahan logam aloi A15052. Seterusnya, bagi penyediaan larutan ujian kakisan, bahan larutan $0.5 \mathrm{M} \mathrm{H}_{2} \mathrm{SO}_{4}$ telah digunakan. Bahan gam Arab disalutkan pada permukaan bahan logam Al5052 menggunakan kaedah pemendapan elektroforesis (EPD) pada nilai voltan $25 \mathrm{~V}$ dan arus sebanyak $0.01 \mathrm{~A}$ selama 30 minit (Besra \& Liu 2008; Bhakat et al. 2018; Mokhtar 2016).

\section{PENCIRIAN BAHAN}

Analisis morfologi dilakukan dengan menggunakan alatan mikroskopi elektron imbasan (SEM), model TM 3000, Hitachi, pada pembesaran 500×. Seterusnya, pengujian rintangan hubungan antara muka (ICR) dilakukan dengan menggunakan alat pengujian keberaliran elektrik rentas satah pada tekanan sebanyak $140 \mathrm{Ncm}^{-2}$, arus elektrik antara $0.1 \mathrm{~A}$ sehingga $1 \mathrm{~A}$, suhu operasi yang divariasikan iaitu $30^{\circ} \mathrm{C}, 50^{\circ} \mathrm{C}, 70^{\circ} \mathrm{C}$ dan $90^{\circ} \mathrm{C}$ dalam Rajah 2. Bagi menyokong analisis morfologi yang dijalankan, ujian kakisan logam asal dan logam disaluti gam Arab menggunakan kaedah elektrokimia dan analisis polarisasi linear tafel dengan mesin potensiostat (Auto lab).

\section{KePUTUSAN DAN PERBINCANGAN}

Bagi melihat perbandingan antara bahan asal dan juga bahan yang telah disaluti gam Arab, analisis morfologi dijalankan.

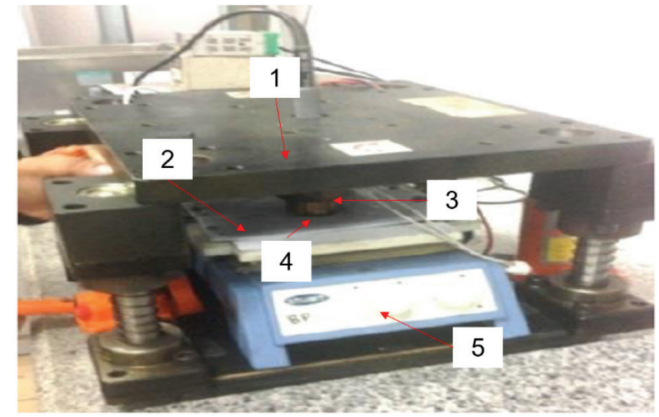

RAJAH 2. Alat pengujian rintangan hubungan antara muka (1) daya mampatan, (2) salutan emas plat (3) kertas karbon (4), logam uji dan (5) mesin pemanas

Rajah 3(a) menunjukkan analisis SEM dengan pembesaran $500 \times$ bagi plat logam Al5052 tanpa salutan gam Arab. Didapati adanya kawasan - kawasan yang telah teroksida kesan daripada kakisan yang berlaku memandangkan sifat semula jadi bahan aluminium tersebut sendiri. Keadaan ini seterusnya akan mengakibatkan prestasi sifat mekanik dan nilai keberaliran elektrik bahan. Namun, keadaan berbeza ditunjukkan oleh analisis SEM dalam Rajah 3(b) dengan tiada pengoksidaan terbentuk pada permukaan plat logam Al5052 setelah disaluti gam Arab, ini menunjukkan permukaan logam terhindar daripada berlakunya kakisan yang membantu meningkatkan prestasi keseluruhan plat dwikutub (Ameh et al. 2012). Salutan yang sempurna amat penting dalam memastikan permukaan tersalut secara sekata dan homogen oleh gam Arab (De Oliveira et al. 2012). Keputusan menunjukkan keratan rentas ketebalan salutan gam Arab iaitu antara $7.4 \mu \mathrm{m}$ sehingga $8.8 \mu \mathrm{m}$ yang ditunjukkan pada Rajah 4. Penemuan ini adalah seiring dengan kajian lepas dengan gam Arab dapat menurunkan kadar kakisan pada logam keluli lembut dengan kaedah perendaman (Othman et al. 2012). Kajian lepas menunjukkan ketebalan maksimum suatu salutan adalah $10 \mu \mathrm{m}$ bagi memastikan rintangan kakisan yang baik diperoleh apabila simulasi sel fuel dijalankan (Wang et al. 2018).

Bagi menilai kesan suhu terhadap kekonduksian plat A15052, uji kaji ICR telah dijalankan dan keputusannya ditunjukkan dalam Rajah 5. Keputusan bagi plat A15052 bahan asal menunjukkan nilai ICR semakin menurun dengan meningkatnya suhu iaitu antara $30^{\circ} \mathrm{C}$ sehingga $90^{\circ} \mathrm{C}$ yang memiliki nilai 11.8552 sehingga $9.9042 \mathrm{~m} \Omega \mathrm{cm}^{2}$. Berbeza dengan plat yang disaluti gam Arab memiliki nilai ICR lebih tinggi pada suhu antara $30^{\circ} \mathrm{C}$ sehingga $90^{\circ} \mathrm{C}$ iaitu sebanyak 13.3497 sehingga $11.8120 \mathrm{~m} \Omega \mathrm{cm}^{2}$. Fenomena yang sama turut diperoleh oleh pengkaji lepas yang disebabkan oleh nilai kepekatan gam Arab yang semakin berkurang pada suhu tinggi (Asri et al. 2016; Mokhtar 2016). Rintangan kakisan diramalkan tinggi dengan kehadiran salutan gam Arab (Mokhtar 2016; Umoren et al. 2008a). Ini adalah kerana nilai rintangan kakisan pada plat aluminium boleh dikaitkan dengan kesan penyerapan gam Arab kerana kehadiran unsur polar iaitu nitrogen $(\mathrm{N})$, oksigen $(\mathrm{O})$ dan 


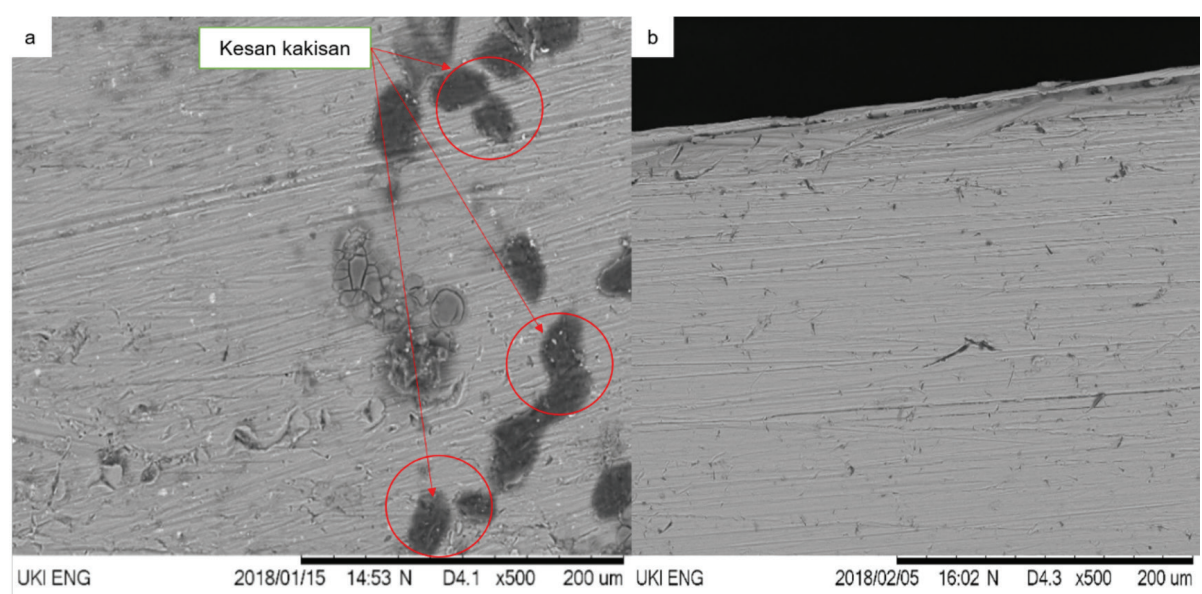

RAJAH 3. Imej SEM bagi (a) Plat logam Al5052 bahan asal dan (b) Plat logam Al5052 bahan disaluti gam Arab

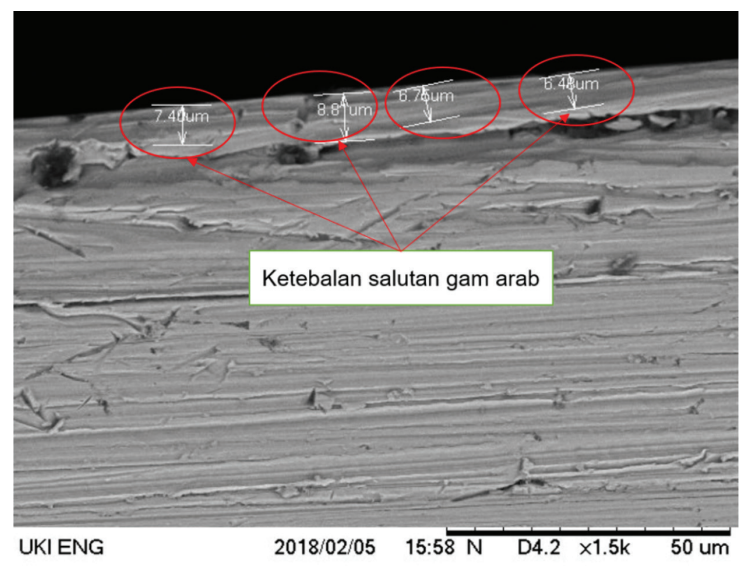

RAJAH 4. Mikrograf SEM bagi keratan rentas ketebalan salutan gam Arab

fosforus (P) yang membentuk lapisan kompleks pada permukaan logam (Umoren et al. 2008b). Umumnya, jumlah arus elektrik yang mengalir melalui bahan yang memiliki rintangan besar adalah kecil. Ini membuktikan gam Arab mampu menghalang daripada berlakunya kakisan pada permukaan logam, seterusnya meningkatkan nilai ICR bagi plat Al5052. Nilai ICR yang diperoleh ini sesuai dengan target DOE iaitu kurang daripada $20 \mathrm{~m} \Omega \mathrm{cm}^{2}$ (Syahram et al. 2012).

Selanjutnya pada Jadual 2 dan Rajah 6 didapati data hasil kajian membuktikan kesan perbandingan laju kakisan untuk plat Al5052 tanpa salutan dan dengan salutan $0.5 \mathrm{~g}$ $\mathrm{L}^{-1}$ gam larutan $0,5 \mathrm{M} \mathrm{H}_{2} \mathrm{SO}_{4}$. Keputusan menunjukkan peningkatan salutan filem pasif pada permukaan logam

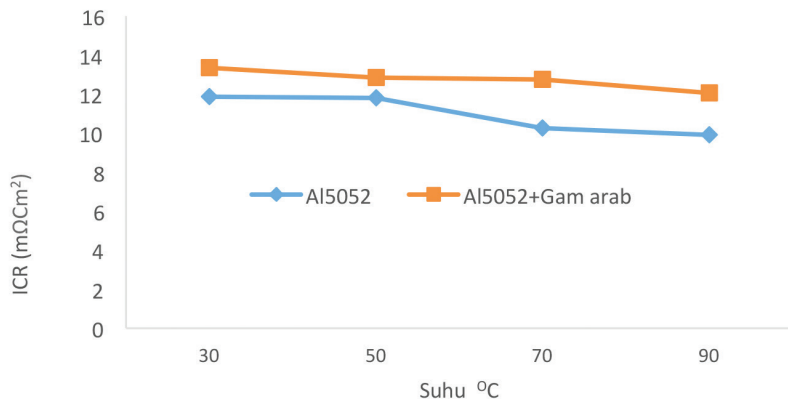

RAJAH 5. Nilai ICR terhadap plat Al5052 pada suhu berbeza

A15052 kerana kesan daripada perencat hijau gam Arab yang ditandai dengan ketumpatan arus kakisan $\left(\mathrm{I}_{\text {corr }}\right)$ menurun daripada 0.00264 menjadi $0.00012 \mu \mathrm{A} \mathrm{cm}^{-2}$. Hal ini sesuai dengan sasaran DOE yang memiliki $\mathrm{I}_{\text {corr }}$ adalah kurang daripada $1 \mu \mathrm{A} / \mathrm{cm}^{2}$. Selain itu, hasil analisis kadar kakisan turut ditentukan berdasarkan luas kakisan pada permukaan logam per tahun (mils per year, mpy). Jadual 2 menunjukkan kadar kakisan logam menurun daripada $3.06 \times 10^{-5}$ mpy kepada $1.61 \times 10^{-6} \mathrm{mpy}$ apabila menggunakan kaedah polarisasi linear tafel. Perihal ini menunjukkan bahawa, kesan gam Arab pada permukaan logam Al5052 dengan menggunakan salutan kaedah EPD dapat menghasilkan salutan yang sekata dan hasil salutan yang stabil.

\section{KESIMPULAN}

Keputusan menunjukkan bahawa dengan kepekatan perencat hijau gam Arab sebanyak $0.5 \mathrm{gL}^{-1}$ dan

JADUAL 2. Ujian kakisan A15053 bahan asal dan bahan yang disaluti gam Arab $0.5 \mathrm{gL}^{-1}$ menggunakan kaedah EPD pada nilai voltan $25 \mathrm{~V}$ dan arus sebanyak 0.01A selama 30 minit

\begin{tabular}{lccccc}
\hline Bahan & $\begin{array}{c}\mathrm{E}_{\text {corr }} \\
(\mathrm{mV})\end{array}$ & $\begin{array}{c}\mathrm{I}_{\text {corr }} \\
\left.(\mu \mathrm{A} \mathrm{cm})^{-2}\right)\end{array}$ & $\begin{array}{c}\beta \mathrm{a}(\mathrm{mV} / \\
\mathrm{dec})\end{array}$ & $\begin{array}{c}\beta \mathrm{c} \\
(\mathrm{mV} / \mathrm{dec})\end{array}$ & $\begin{array}{c}\text { Halaju kakisan } \\
(\mathrm{mpy})\end{array}$ \\
\hline A15052 & -454.29 & 0.00264 & 59.52 & 55.94 & $3.06 \times 10^{-5}$ \\
A15052+gam Arab & -427.17 & 0.00012 & 98.75 & 99.55 & $1.61 \times 10^{-6}$ \\
\hline
\end{tabular}




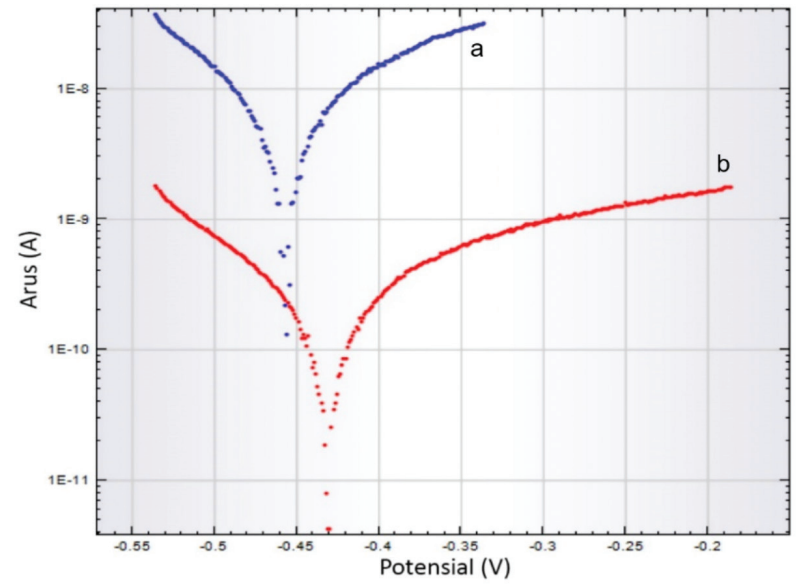

RAJAH 6. Keputusan ujian polarisasi linear tafel plat A15053 bagi (a) Bahan asal dan (b) Bahan disaluti gam Arab $0.5 \mathrm{gL}^{-1}$ menggunakan kaedah EPD pada nilai voltan $25 \mathrm{~V}$ dan arus sebanyak $0.01 \mathrm{~A}$ selama 30 minit

menggunakan kaedah salutan EPD boleh mengurangkan kakisan plat A15052 serta memanjangkan jangka hayat bahan. Pencirian bahan mendapati logam A15052 yang telah disaluti gam Arab boleh mencapai piawai yang ditetapkan oleh DOE untuk plat dwikutub PEMFC iaitu nilai ICR sebanyak 13.3497 sehingga $11.8120 \mathrm{~m} \Omega \mathrm{cm}^{2}$ dan $\mathrm{I}_{\text {Corr }}$ $0.00012 \mu \mathrm{A} \mathrm{cm}^{-2}$.

\section{PENGHARGAAN}

Penghargaan diberikan kepada Kementerian Pelajaran Tinggi Malaysia yang membiayai kajian melalui geran penyelidikan LRGS/2013/UKM-UKM/TP-01 dan Universiti Kebangsaan Malaysia GUP-2016-044.

\section{RUJUKAN}

Antonelli, E., Silva, R.S., Bernardi, M.I.B. \& Hernandes, A.C. 2013. Electrophoretic deposition of BaTi0.85Zr0.15O3 nano powders. Materials Research 16(6): 1344-1349.

Antunes, R.A., de Oliveira, M.C.L., Ett, G. \& Ett, V. 2011. Carbon materials in composite bipolar plates for polymer electrolyte membrane fuel cells: A review of the main challenges to improve electrical performance. Journal of Power Sources 196(6): 2945-2961.

Antunes, R.A., Oliveira, M.C.L., Ett, G. \& Ett, V. 2010. Corrosion of metal bipolar plates for PEM fuel cells: A review. International Journal of Hydrogen Energy 35(8): 3632-3647.

Ameh, P.O. 2014. Inhibitory action of Albizia zygia gum on mild steel corrosion in acid medium. African Journal of Pure and Applied Chemistry 8(2): 37-46.

Ameh, P.O., Magaji, L. \& Salihu, T. 2012. Corrosion inhibition and adsorption behaviour for mild steel by Ficus glumosa gum in $\mathrm{H}_{2} \mathrm{SO}_{4}$ solution. African Journal of Pure and Applied Chemistry 6(7): 100-106.

Asri, N.F., Husaini, T., Abdullah, A.R., Sulong, A.B., Ramli, W.D.W. \& Majlan, E.H. 2017. Interfacial contact resistance for Ti-6Al-4V and SUS 316L plates as bipolar plates in PEMFC. Journal of Mechanical Engineering, Electrical Engineering 24(4): 1436-1442.
Asri, N.F., Husaini, T., Sulong, A.B., Majlan, E.H. \& Daud, W.R.W. 2016. Coating of stainless steel and titanium bipolar plates for anticorrosion in PEMFC: A review. International Journal of Hydrogen Energy 42(14): 1-14.

Babu, R.S., de-Barros, A.L.F., de-Almeida, M.M., da-Motta, S.D., Balamurugan, J. \& Lee, J.H. 2018. Novel polyaniline/ manganese hexacyanoferrate nanoparticles on carbon fiber as binder-free electrode for flexible supercapacitors. Composites Part B: Engineering. 143: 141-147.

Besra, L. \& Liu, M. 2006. A review on fundamentals and applications of electrophoretic deposition (EPD). Prog. Mater. Sci. 52(1): 1-61.

Bhakat, D., Barik, P. \& Bhattacharjee, A. 2018. Electrical conductivity behavior of gum Arabic biopolymer-Fe3O4 nanocomposites. Journal of Physics and Chemistry of Solids 112: 73-79.

Chiang, T.Y., Ay-Su, Tsai, L.C., Sheu, H.H. \& Lu, C.E. 2014 Corrosion resistance of 5052 Al-alloy with a Zirconia-rich conversion coating used in bipolar plates in PEMFCs. International Journal of Electrochemical Science 9(11): 5850-5863.

Dadfar, M., Salehi, M., Golozar, M.A. \& Trasatti, S. 2016. Surface modification of 304 stainless steels to improve corrosion behavior and interfacial contact resistance of bipolar plates. International Journal of Hydrogen Energy 41(46): 2137521384.

De Oliveira, M.C.L., Ett, G. \& Antunes, R.A. 2012. Materials selection for bipolar plates for polymer electrolyte membrane fuel cells using the Ashby approach. Journal of Power Sources 206: 3-13.

Feng, K., Li, Z., Sun, H., Yu, L., Cai, X., Wu, Y. \& Chu, P.K. 2013. Short communication $\mathrm{C} / \mathrm{CrN}$ multilayer coating for polymer electrolyte membrane fuel cell metallic bipolar plates. Journal of Power Sources 222: 351-358.

García, M.A.L. \& Smit, M.A. 2006. Study of electrodeposited polypyrrole coatings for the corrosion protection of stainless steel bipolar plates for the PEM fuel cell. Journal of Power Sources 158(1): 397-402.

Hermann, A., Chaudhuri, T. \& Spagnol, P. 2005. Bipolar plates for PEM fuel cells: A review. International Journal of Hydrogen Energy 30(12): 1297-1302.

Hou, K.H. 2011. Analysis on the corrosion behavior of Al-alloy bipolar plate and $\mathrm{pH}$ value of water product for the PEMFC. International Conference on Environment Science and Engineering 8: 313-317.

Huang, N.B., Yu, H., Xu, L.S., Zhan, S., Sun, M. \& Kirk, D.W 2016. Corrosion kinetics of 316L stainless steel bipolar plate with chromiumcarbide coating in simulated PEMFC cathodic environment. Results in Physics 6: 730-736.

Mehta, V. \& Cooper, J. 2003. Review and analysis of PEM fuel cell design and manufacturing. Journal of Power Sources 114(1): 32-53.

Radzuan, N.A.M., Zakaria, M.Y., Sulong, A.B. \& Sahari, J. 2017. The effect of milled carbon fibre filler on electrical conductivity in highly conductive polymer composites. Composites Part B: Engineering 110: 153-160.

Mokhtar, L. 2016. Electric conductivity of gum arabic from Acacia senegal. International Journal of Science and Research 5(2): 583-593.

Othman, A., Abu-Dalo, M.A. \& Al-Rawashdeh. 2012. Exudate gum from acacia trees as green corrosion inhibitor for mild steel in acidic media. International Journal of Electrochemical Science 7: 9303-9324. 
Patni, N.,Agarwal, S. \& Shah,P. 2013. Greener approach towards corrosion inhibition. Chinese Journal of Engineering 2013: $1-10$.

Pech-Rodríguez, W.J., González-Quijano, D., Vargas-Gutiérrez, G. \& Rodríguez-Varela,F.J. 2014. Electrophoretic deposition of polypyrrole/Vulcan XC-72 corrosion protection coatings on SS-304 bipolar plates by asymmetric alternating current for PEM fuel cells. International Journal of Hydrogen Energy 39(29): 16740-16749.

Peter, A. \& Sanjay, I.B.O. 2015. Use of natural gums as green corrosion inhibitors: An overview. International Journal of Industrial Chemistry 6(3): 153-164.

Raddaha, N.S., Cordero-Arias, L., Cabanas-Polo, S., Virtanen, S., Roether, J.A. \& Boccaccini, A.R. 2014. Electrophoretic deposition of chitosan/h-BN and chitosan/h-BN/TiO2 composite coatings on stainless steel (316L) substrates. Materials 7(3): 1814-1829.

Rani, B.E.A.\& Basu, B.B.J.2012. Green inhibitors for corrosion protection of metals and alloys: An overview. International Journal of Corrosion 2012: Article ID 380217.

Sangeetha, M., Rajendran, S., Muthumegala, T.S. \& Krishnaveni. 2011. Green corrosion inhibitors - an overview. Zastita Materijala 52: 3.

Shahram, K., Norman, F., Bronwyn, R. \& Frank, R. 2012. A review of metallic bipolar plates for proton exchange membrane fuel cell: Materials an fabrication methods. $J$. Advances in Materials Science 2012: Article ID 828070.

Tawfik, H., Hung, Y. \& Mahajan, D. 2007. Metal bipolar plates for PEM fuel cell - A review. Journal of Power Sources 163(2): 755-767.

Umoren, S.A., Obot, I.B. \& Ebenso, E.E. 2008a. Corrosion inhibition of aluminium using exudate gum from Pachylobus edulis in the presence of halide ions in $\mathrm{HCl}$. E-Journal of Chemistry 5(2): 355-364.

Umoren, S.A., Obot, I.B., Ebenso, E.E. \& Okafor, P.C. 2008b. Eco-friendly inhibitors from naturally occurring exudate gums for aluminium corrosion inhibition in acidic medium. Portugaliae Electrochimica Acta 26(3): 267-282.

Wang, X.Z., Muneshwar, T.P., Fan, H.Q., Cadien, K. \& Luo, J.L. 2018. Achieving ultrahigh corrosion resistance and conductive zirconium oxynitride coating on metal bipolar plates by plasma enhanced atomic layer deposition. Journal of Power Sources 397: 32-36.
Woodman, A.S., Anderson, E.B., Jayne, K.D., Kimble, M.C \& Kimble, M.C. 1999. Development of corrosion-resistant coatings for fuel cell bipolar plates. Physical Sciences 978: $1-9$.

Yang, Y., Guo, L. \& Liu, H. 2010. Corrosion characteristics of SS316L as bipolar plate material in PEMFC cathode environments with different acidities. International Journal of Hydrogen Energy 36(2): 1654-1663.

I Gusti Ayu Arwati, Edy Herianto Majlan*, Wan Ramli Wan Daud, Loh Kee Shyuan, Khuzaimah Binti Arifin, Teuku Husaini \& Nabilah Afiqah Mohd Radzuan Institut Sel Fuel

Universiti Kebangsaan Malaysia 43600 UKM Bangi, Selangor Darul Ehsan Malaysia

Wan Ramli Wan Daud

Pusat Penyelidikan Teknologi Proses Mampan

Universiti Kebangsaan Malaysia

43600 UKM Bangi, Selangor Darul Ehsan Malaysia

I Gusti Ayu Arwati \& Sagir Alva

Mechanical Engineering Department

Engineering Faculty

Mercu Buana University

11650 Jakarta

Indonesia

*Pengarang untuk surat-menyurat; email: edyhm71@gmail.com

Diserahkan: 9 Julai 2018

Diterima: 29 September 2018 